\title{
The Factors Influencing Clients E-Trust in Online Banking Systems in Jordan
}

\author{
Dr. Adel A. Salloum \\ Management Information Systems Department, \\ School of Business, Mutah University, Jordan
}

\begin{abstract}
This study aimed to reveal the factors affecting the e-trust in online banking systems in Jordan, through a group of dimensions that affect e-trust, to achieve the objective of this study the researchers prepare a questionnaire that include (29) paragraph, to collect the primary information from the study sample, and then collecting, analyzing the data and testing the hypotheses using SPSS, the study sample consisted of (120) respondents . Different statistical methods were used to achieve the objectives of the study. the paper revealed that there is statistically significant relationship between the online banking system dimensions (Information quality, System use, Perceived value, Imposed commission (service price), Social factors (Familiarity ,Empathy ,Equity)) and the customer e-trust in online banking systems. A set of recommendations were proposed to enhance customer's e-trust and guide decision makers in the banking sector to boost their clients' trust in online banking systems through a long term strategy 5 to develop the online systems.
\end{abstract}

\section{Introduction:}

Information technologies have been infused in almost all aspects of our professional and personal lives. The tremendous capabilities of Information Technology (IT) in processing, storing, and retrieving information has resulted in fast growth in 
computer usage. Growth in computer usage represents the fastest diffusion of technology in human history (Igbaria, et al., 1998). Financial institutions realized the tremendous advantages of the Internet developments by making their services provision more internet based in order to improve the ways by which financial services are delivered. Gradually, banks worldwide have started to develop a full-scale network of e-banking and nowadays, most banks customers are getting more familiar with e-banking service offered. Yet, a small portion of customers are using e-banking services especially in the developing countries (Katuri \& Lam, 2007). Banks consumers' adoption of e-banking services in Jordan, which is considered as one of the developing countries, has been slower than anticipated. For instance, the data published by the central bank of Jordan in 2014 revealed that only $13 \%$ of the customers are using e-banking services in Jordan which is the lowest in Arab countries (CBJ, 2014).

The fact that e-banking services adoption is still in its infant stages proves that the successful implementation of information systems is dependent on the extent to which such a system is used or utilized by potential users (Venkatesh, et al., 2003). Consequently, In order to motivate customers to use e-banking systems, banks must make key improvements that address the customers' concerns by focusing and understanding the key factors influencing the adoption of e-banking services. However, it has been recognized that understanding the reasons behind accepting or rejecting computer systems such as internet banking is one of the most challenging issues in information system research, especially in Jordan (Abu-Assi et al., 2014).

Among the factors that influences the adoption of e-banking systems and determines customer satisfaction is trust in online banking system, which captured the attention of many researchers (Morrison \& Firmstone 2000, Salam, et.al .2005, El- 
Said and Jalal edeen, 2009). In Jordan, studies have also revealed that banks customers have high perceived risk, distrust and lack of e-banking awareness (Al Sukkar \& Hasan, 2005; Siam, 2006). Electronic trust, or so-called e-trust, is primarily related to the willingness to be vulnerable to others' actions and/or the level of confidence or the possibility of verification that owned by consumer in making his dealing or completing his transactions (Mayer, et.al, 1995). Table 2 below, demonstrates various definitions of e-trust, however, the current study defined e-trust as the level of confidence or the possibility of verification that owned by consumers in making there online dealings or completing there online transactions (Reichheld \& Schefter ,2000).

In this study clients' e-trust in online banking systems is considered as the dependent variable and hence, the current study aims to investigate the impact of technical, economic and social factors, which are dealt with as the independent factors. The reason behind paying considerable attention on e-trust in online banking systems from the client perspective is that most of researchers, academics and practitioners in the banking industry put most of their emphasis on enabling financial institutions to gain a competitive advantage derived from the investment in IT components to provide high quality services, while few of them do not focus on building e-trust as part of an ongoing relationship between the bank and its clients. Thus, it was revealed that failure or lack of building client's trust in online banking systems was the main cause, which leads visitors to not returning to the visited online systems (Li-Chang, et.al 2008). 


\section{Research Problem and Questions:}

E-banking services are facing many difficulties and problems particularly in the developing countries and Jordan, which is based in the Middle East region and a part of the Levant countries, is not an exception. It should be noted that Jordan is considered as one of the pioneering countries that took the move toward the provision of internet banking services to clients (AlKailani, 2016). In addition great improvements in the infrastructure of Jordanian banks, which is mainly based on the adoption of electronically enabled banking services have been made, however, E-banking services are still to be considered in its infancy (Alsamydai et al. 2014).

Trust has been viewed as one of the most prominent factors hindering people from adopting modern and advanced information technology due to potential information security, privacy and identity threat vulnerabilities (AlKailani, 2016). Currall and judge (1995) defined trust as "An individual reliance on another party under conditions of dependence and risk", this risk can be greater when money is involved and sensitive information is exchanged in transactions as in the case of internet banking. Therefore, Trust significantly influences clients intention to use Internet banking and is considered as crucial driver of Internet banking adoption.

This study aims to identify the main factors influencing e-trust in online banking systems in Jordan from the client's perspective. Per se the research problem would be "What are the factors affecting Customer E-Trust in Online Banking Systems in Jordan"

The following research questions were considered worthy of investigation: 
1. Do technical factors (information quality and system use) have an impact on the e-trust in online banking systems?

2. Do economic factors (Perceived value and imposed commission) have an impact on the e-trust in online banking systems?

3. Do social factors (Familiarity, Empathy, and Equity) have an impact on the e-trust in online banking systems?

\section{Research Objectives:}

The previous discussion of trust in online banking systems in Jordan pinpoints the need to further understand and formulate a model of factors influencing e-trust in such systems. Therefore, the following research objectives were considered worthy of exploration:

1. To explore the concept of e-trust in online banking system in Jordan and determine the level of e-trust in online banking systems

2. To determine the impact of technical factors on e-trust in online banking systems

3. To determine the impact of economic factors on e-trust in online banking systems

4. To determine the impact of social factors on e-trust in online banking systems

\section{Research Importance:}

Traditional offline branches is still considered as the main distribution channel for delivering banking services to the target clients and remains the most used method for conducting banking transactions in Jordan and in any other country (AbuAssi et al. 2014). Though, internet based technology has been widely used in the banking sector and increasingly changing the 
business model by which banking services are offered in order to improve efficiency, quality and boost profitability through internet-based E-banking systems. In spite of the tremendous advantages that internet banking systems provide to both sides of the financial transaction (i.e. the bank the target client), usage rate of these systems is still below the promising level.

Trust has been proposed as one of the major obstacles that prevent individuals from adopting the online technology (Gefen et al. 2003). Consequently, it is imperative to identify and understand what makes bank clients trust online banking systems to promote their acceptance and usage banking. Moreover, this study can be a framework of reference for decision makers in the banking sector in Jordan to design and develop safer and more trusted internet banking systems to achieve client satisfaction.

\section{Theoretical Framework and Model Formulation: Online Banking Concept:}

E-Banking has emerged in the early nineties of the last century to refers to a key point, namely that the client manages his financial transactions, bank accounts, and any financial and banking services that he/she wants to receive from the bank, from his office, home or anywhere and anytime (Alsamydai et al. 2014). Therefore, E-banking denotes to the provision of financial services and banking products through electronic delivery channels.

The Hashemite kingdom of Jordan (Jordan for short) is situated in the Middle East, sharing boarders with Syria (North border), kingdom of Saudi Arabia (South borders), Iraq to the East, and Palestine to the West. Jordan has a population of 10 million people, mostly middle income. To achieve a competitive advantage and increase the responsiveness to customers' needs 
with lower cost, many banks in Jordan have adopted Internet banking (Siam, 2006). Recently, the one can notice an increasing number of banks in Jordan that have been implementing more advanced and modernized information technologies to provide banking services in better quality and less cost (Abu Assi et al. 2014).

Banks clients have shown an interest in using Electronic banking applications to facilitates access to their accounts and executing transactions electronically in an easier way through visiting the bank websites at any time. In utilizing this facility, individuals and companies are saving a lot of their time and money (Alsamydai et al. 2014).

E-banking offers electronic services that allow consumers to check the balances in their accounts, transfer funds among accounts, pay bills electronically as well as apply for loans, download information about their accounts into their own computers, trade stocks or mutual funds (Alsamydai et al. 2014). Thus, the enormous benefits of online banking have led to the widespread and adoption of internet banking by most banks working in Jordan

\section{Factors affecting the Adoption of Online}

\section{Banking:}

Nowadays, the electronic technology is playing a major role for businesses especially in banking activities. Electronic banking is the newest delivery channel for banking services. E-banking has become increasingly common, employed by many financial institutions to reduce costs associated with having personnel serve customers physically, shorten processing periods, increase speed, improve the flexibility of business transactions and provide better service overall (Shih and Fang, 2004). With the rapid growth of Internet technology, online banking has played an important role in the e-payment field which provides an 
online transaction platform to support many e-commerce applications such as online shopping, online auction and Internet stock.

Clearly, to promote client's adoption of internet banking, banks must make key improvements that address consumer concerns. Thus, it would be useful for financial institutions to gain a vivid understanding of the key factors that influence clients' internet banking adoption. Table 1 summarizes the factors affecting the adoption of online banking systems reviewed from previous research conducted.

Table 1: Factors Affecting the Adoption of Online Banking Systems

\begin{tabular}{|c|c|c|}
\hline Authors & $\begin{array}{l}\text { Title of study } \\
\end{array}$ & $\begin{array}{l}\text { Factors } \\
\end{array}$ \\
\hline $\begin{array}{l}\text { AlKailani } \\
\text { (2016) }\end{array}$ & $\begin{array}{l}\text { Factors Affecting the } \\
\text { Adoption of Internet } \\
\text { Banking in Jordan: } \\
\text { An Extended TAM Model }\end{array}$ & $\begin{array}{c}\text { Perceived Usefulness, } \\
\text { Perceived Ease of Use, Bank } \\
\text { credibility, Perceived Risk, } \\
\text { Perceived Trust }\end{array}$ \\
\hline $\begin{array}{c}\text { Perkins and } \\
\text { Annan (2013) }\end{array}$ & $\begin{array}{c}\text { Factors affecting the } \\
\text { Adoption of Online Banking } \\
\text { in Ghana: Implications for } \\
\text { Bank Managers }\end{array}$ & $\begin{array}{c}\text { Perceived Usefulness, } \\
\text { Perceived Ease of Use, } \\
\text { Governmental Support, Trust } \\
\text { \& Security }\end{array}$ \\
\hline $\begin{array}{l}\text { Sohrabi, Yee } \\
\text { and Nathan } \\
(2013)\end{array}$ & $\begin{array}{c}\text { Critical success Factors for } \\
\text { the adoption of e banking in } \\
\text { Malaysia }\end{array}$ & $\begin{array}{l}\text { Trust perception, charges/cost } \\
\text {, privacy, security }\end{array}$ \\
\hline Nasri (2011) & $\begin{array}{l}\text { Factors Influencing the } \\
\text { Adoption of Internet } \\
\text { Banking in Tunisia }\end{array}$ & $\begin{array}{c}\text { Channel convenience, } \\
\text { Information on online banking } \\
\text {, Perceived risk, Prior Internet } \\
\text { knowledge, Demographic } \\
\text { Characteristics(Age- Gender - } \\
\text { Occupation- Instruction), } \\
\text { Security perception (trust) } \\
\end{array}$ \\
\hline $\begin{array}{l}\text { Margaret and } \\
\text { Thompson } \\
(\mathbf{2 0 0 0 )}\end{array}$ & $\begin{array}{c}\text { Factors Influencing the } \\
\text { Adoption of Internet } \\
\text { Banking }\end{array}$ & $\begin{array}{c}\text { Relative Advantage } \\
\text {,Compatibility (Values - } \\
\text { Internet experience - Banking } \\
\text { needs ),_Complexity , Risk } \\
\text { (trust), Self-efficacy, } \\
\text { Facilitating Conditions, } \\
\text { Availability of Government } \\
\text { Support, Availability of } \\
\text { Technology Support } \\
\end{array}$ \\
\hline
\end{tabular}


As shown in Table 1, the studies concluded that trust is a prominent factor, which affects the adoption of online banking systems by clients in Jordan. However, to the knowledge of the researcher, few studies concentrated on studying the influencing factors on trust as a dependent variable instead of being viewed as an independent variable.

According to Perkins and Annan (2013) trust was perceived to be profoundly paramount when it comes to online banking adoption and acceptance, and emphasized the importance of obtaining proper understanding of the factors that can motivate or strengthen clients trust in using internet banking systems. In addition, Perkins and Annan (2013) recommended that banks managers should take into consideration online trust (i.e. e-trust) when such banking systems are designed and developed.

Moreover, a survey conducted by Computer Fraud and Security (2007) concluded that $(82 \%)$ of clients were doubtful to reply to emails from their banks, $(52 \%)$ of clients rejected any sign-up for online banking as they were more concerned about the security and privacy of online banking systems.

In his study, Nasri (2011) referred to trust as the security of the system and postulated that trust was considered as one of the very important factors in determining the decision of clients to use Internet banking, and unless security is improved, more bank clients would be willing to conduct their banking transactions electronically over the Internet.

As a consequence, it is imperative to depict the most significantly influencing factors on e-trust in online banking systems in Jordan from the perspective of clients as they are the intended target users of banking online systems, and that's what will be discussed in the next section. 


\section{Factors influencing e-trust in online banking} systems in Jordan:

Numerous definitions of trust have been used to reflect its complicated nature (Baraghani, 2009), conducting a banking transaction electronically by utilizing the Internet is a form of a trusting behavior as the client relies and be dependent on the Internet to perform the transaction. According to Rousseau et al. (1998) the underlying premise of trust requires that the one should be willing to be vulnerable and holds positive expectations of the bank and/or the Internet offering online banking services. Table 2 reveals different definition of trust construct.

\section{Table 2: Definitions of Trust}

\begin{tabular}{|l|l|}
\hline $\begin{array}{l}\text { Trust is "the belief that a party's word or promise is reliable } \\
\text { and a party will fulfil his/her obligations in an exchange } \\
\text { relationship". }\end{array}$ & Rotter (1967) \\
\hline $\begin{array}{l}\text { Trust occurs "when one party has confidence in an exchange } \\
\text { partner's reliability and integrity". }\end{array}$ & $\begin{array}{l}\text { Morgan and } \\
\text { Hunt (1994) }\end{array}$ \\
\hline $\begin{array}{l}\text { Trust is "the willingness of a party to be vulnerable to the } \\
\text { actions of another party based on the expectation that the } \\
\text { other will perform a particular action important to the } \\
\text { trustor, irrespective of the ability to monitor or control that } \\
\text { other party". }\end{array}$ & $\begin{array}{l}\text { Mayer et al. } \\
\mathbf{( 1 9 9 5 )}\end{array}$ \\
\hline $\begin{array}{l}\text { Trust is a "psychological state comprising the intention to } \\
\text { accept vulnerability based upon positive expectation of the } \\
\text { intentions or behavior of another". }\end{array}$ & $\begin{array}{l}\text { Rousseau et al. } \\
\mathbf{( 1 9 9 8 )}\end{array}$ \\
\hline $\begin{array}{l}\text { Trust on an online vendor is the "willingness to make oneself } \\
\text { vulnerable to actions taken by the trusted party based on the } \\
\text { feeling of confidence and assurance". }\end{array}$ & Gefen (2000) \\
\hline $\begin{array}{l}\text { Trust is "the subjective assessment of one party that another } \\
\text { party will perform a particular transaction according to his } \\
\text { or her confidence expectation, in an environment } \\
\text { characterized by uncertainty". }\end{array}$ & $\begin{array}{l}\text { Ba and Pavlou } \\
(2002)\end{array}$ \\
\hline $\begin{array}{l}\text { The absence of an offline real interaction between the bank and } \\
\text { its client is considered a major obstacle in online banking arena. } \\
\text { This obstructing nature of Internet banking made client's trust in }\end{array}$ \\
\hline
\end{tabular}


using such an online banking system a primary future challenge to be considered seriously (Aladwani, 2001). Thus, banks should pay more attention in building a mutually valuable relationship with their customers through a trust-based collaboration process (Dayal et al., 1999).

\section{Study model:}

Internet banking adoption/acceptance as well as the factors affecting customers' acceptance and usage of internet banking services have received substantial consideration by several researchers in spite of the fact that a small part of the literature investigated the factors affecting customers' e-trust in online banking systems. Based on these studies the current study model was developed as shown in Figure 1

Figure 1: Study Model

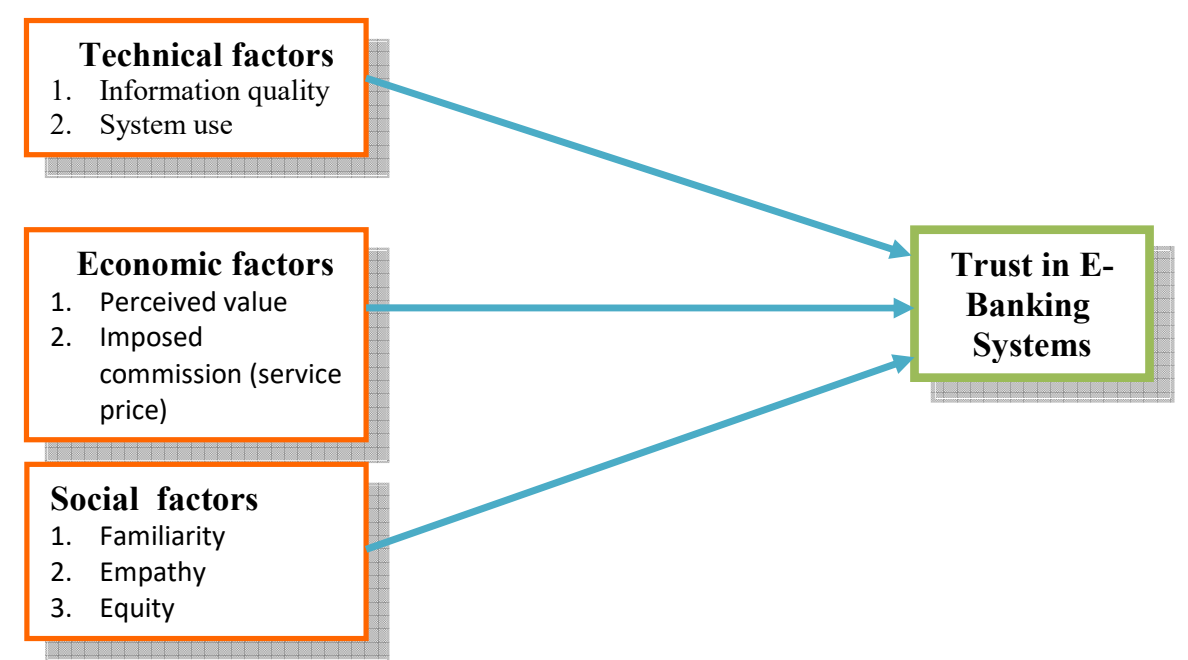


Technical Factors: technical factors encompass information quality and system use (Liljander \& Strandvik 1995). Below is an explanation of both information quality and system use

Information Quality: This variable is concerned with the provision of information that contributes to solving customer problems when interacting with online banking systems. Information quality can be improved through personalization of websites in a form of making a personalized page (profile) for the customer in the system. Initiating such a profile helps clients to get their private information in a secured and private manner (Henczel 2004). Lee et al. (2000) suggested that online clients will be more satisfied with the website if the information provided to them is of high quality and sufficient that provides a sense of security and in turn helps to build e-trust. So that E trust comes through the high quality information that is accessible through the consumer profile personally.

System Design: One of the important issues in the use of online banking systems is design, which meets the needs of customers and helps banks to gain a competitive advantage and therefore attracts more customers (Kang \& Kim 2006, Lee \& Kozar 2006).Corbitt et al. (2003) argued that website design quality, which is comprised of various aspects such as website response time, navigation capability and user experience is crucial and reflects the banks' image that is essential for building trust in using the online banking system. To assess the impact of website design on e-trust, it must be noted that the completion of the transaction stages, ease of use and privacy are amongst the issues that provide evidence for the client to trust the internet banking system (Allen, 1996). 


\section{Economic Factors:}

Perceived Value: Perceived value contributes to trust in online business by reducing an individual's need to seek alternative service providers (Chang et al., 2009). Zeithaml (1988) defined value as "the consumer's overall assessment of the utility of a product based on perceptions of what is received and what is given". Typically, when customers feel that they are not getting the best value for their money, they will begin searching for alternatives, which means that their trust often declines dramatically. The association between perceived value and customers' trust to transact has been proven to be positive by many studies (Dai et al. 2008; Chang \& Wang 2011). Luarn and Lin (2003) concluded that perceived value is associated with trust both positively and directly and this conclusion is the same as Quan (2010) showed a significant relationship between perceived value and trust.

Imposed Commission (service price): Although imposed commission is considered as a prominent factor affecting clients' decisions to utilize online banking systems, imposed commission influence on e-trust is still unclear (Chiang \& Dholakia 2003; Chiou et al. 2010). Jiang and Rosenbloom (2005) examined the role of service price on customer's retention and trust in online services and found that the service price correlates positively with customer trust in online services. In addition, Swaid and Wigand (2009) consider price an important variable affecting trust behavior.

Social Factors: Morris et al (1998) and Perry et al (2002) postulated that there are various social factors such as familiarity, empathy and equity. These social factors explain the nature of the relationship between the institution (i.e. providing the service) and its customers (Berry 1995). Below, is an 
explanation of the three variables that comprise the social factors category:

Familiarity: Familiarity refers to the perceived "distance" of body, soul, and emotion among people (Barnes, 1997). (Heider, 1958) articulated that consumers tend to deal positively with those institutions who had with them past successful cooperation. Thus, the shorter the perceived distance between online bank and customer is, the more likely the relationship would be seen familiar (Nielson, 1998). This means that the more online customer experience, the greater chances of familiar relationship with institutions, and hence more e-trust in them. The designer of the bank website must have an ability to predict when the customer needs information and interact with the website and meet his desires. Thereby increasing the exchange of information and reduce the distance between the bank and the customer leads to more familiar relationship and therefore greater e- trust (Zhang, 2001).

Empathy: Empathy from the economic perspective means that the company should be able to understand the needs and interests of its customer (Phillips, 2004). By understanding actual customers' preferences and behavior, banks can have a closer look at the emotional structure of customers and meet their needs. When the bank satisfies its customers' needs, it will definitely result in a higher level of empathy and consequently, leads to a higher level of e-trust.

Equity: Equity refers to the variance between the inputs (costs, sacrifices or the price) that the customer pays to have a a service and the outcomes that they receive from it compared to the perceived inputs and outcomes of others (Adams, 1965). This means that equity does not depend on input-to-output ratio alone; it also depends on the comparison between the ratio of one part and the ratio of others. The application of equity on 
online banking research shows that this perception can influence the customer's decision, either negatively or positively when the client views the output (rewards) are more than the inputs (efforts)

Research hypotheses: Based on the objectives of the current study as well as the study's model (see Figure 1), the hypotheses of the study were formulated to reflect the variables affecting clients' e-trust in online banking systems. The hypotheses listed are the alternate hypotheses, which reflect the researcher's convictions about the theory in hand (Sekaran, 2003). The alternate hypotheses are divided into three main hypotheses and their sub hypotheses:

The First main hypotheses: H1: The independent variables (technical, economic and social variables) taken together have a direct influence on customers' e-trust in online banking systems

The Second main hypotheses: H2: The independent variables (technical, economic and social variables) taken separately have a direct influence on customers' e-trust in online banking systems

The Third main hypotheses: H3: There is a difference in customers' e-trust in online banking systems due to the clients' demographics (gender, age, qualification and use of internet) taken separately

\section{Research Methodology and Design:}

Study Population and Sample: This research adopted the quantitative survey as the main research strategy that is usually adopted by most of social science scholars to test the study hypotheses and verify the research model. Additionally, this study aims to investigate the factors affecting the clients' e-trust 
in online banking systems in Jordan and therefore, the population for this study was all the electronic banking service clients of Arab banking corporations in Jordan. A sample of (120) clients using online banking systems of three banks in Jordan; the Bank of Jordan, Jordan Islamic Bank and Housing Bank for Trade and Finance were chosen to constitute the sample of this study. The sample subjects were taken from the branches dispersed in the southern part of Jordan, specifically Karak district.

Data Sources and Collection Method: Two types of data were used in this study; primary and secondary data. Secondary data obtained from the existing literature and previous studies related to the topic of the research in order to obtain a vivid understanding of the topic in hand. Secondary data was collected from two sources; firstly Mutah university's academic databases (e.g. EBSCO, ScienceDirect) and the available library's materials, secondly Internet based publications such as research articles and online books where Google Scholar was mainly used. Internet search phrases used were "e-trust", "online banking systems", "electronic banking in Jordan", "Internet banking" and in conjunction with "influencing factors", and "variables".

Primary data were collected from the study sample objects by distributing a survey questionnaire as the research collection method for the primary data. The questionnaire was prepared based on the prior research and the literature review. The questionnaire included three separate sections; the first section was dedicated to collect data about the sample characteristics, the second section was intended to measure the independent variables listed in the study model (see Figure 1) and the third section was intended to measure the dependent variable (i.e. etrust in online banking systems). The study used a five-point 
Likert scale from 1 to 5 , rating from strong disagreement to strong agreement.

Total number of (120) questionnaires were distributed and returned; only (112) were usable. The other (8) questionnaires were unusable because the respondents had left some questions unanswered and/or their responses were unusual in terms of, for instance, selecting a specific point of scale to answer all the questionnaire items. The response rate of the survey was $93 \%$, which was $(112 / 120)$ respondents. Table 3 illustrates the distribution of questionnaires and the rate of return.

Table 3: Distribution of Questionnaires

\begin{tabular}{|c|l|}
\hline Number of respondents & \multicolumn{1}{c|}{ The Bank } \\
\hline 37 & The bank of Jordan \\
\hline 35 & Jordan Islamic bank \\
\hline 40 & Housing Bank for Trade and Finance \\
\hline 112 & Total \\
\hline
\end{tabular}

Data Analysis and Findings: In this section the researcher introduces a discussion of the data analysis and test of the hypotheses and the findings. Several statistic techniques were used including Cronbach's alpha, frequency analysis, descriptive analysis, and regression test. Before analyzing the primary data from the returned completed questionnaires, data was codified to facilitate the transformation of participants' responses on the questionnaire items into computer files so that computers could provide the researcher with meaningful information, the SPSS (Version 18) was the main data analysis tool.

Test of reliability: Cronbach's alpha is a reliability coefficient that indicates how well the items, which constitute a variable, are positively correlated to one another (Abu Assi, 2014). Cronbach's' Alpha of $70 \%$ or higher is considered acceptable in most social science research. The result of this test in the current study is $90 \%$ for the independent variables and 
$87 \%$ for the dependent variable, which is acceptable and considered high for the current study as shown in Table 4.

Table 4: Reliability Coefficients

\begin{tabular}{|c|l|c|}
\hline Reliability coefficient & \multicolumn{1}{|c|}{ Dimension } & \multirow{2}{*}{ Variable } \\
\hline 0.87 & Information quality & \multirow{2}{*}{ E-banking system } \\
\hline 0.86 & System design & \\
\hline 0.85 & Perceived value & $\begin{array}{l}\text { Imposed commission } \\
\text { (service price) }\end{array}$ \\
\cline { 1 - 2 } 0.87 & Social factors & \\
\hline 0.83 & \multicolumn{2}{|c|}{ Total } \\
\hline 0.90 & \multicolumn{2}{|c|}{ E- trust in online banking system } \\
\hline 0.87 &
\end{tabular}

Characteristics of the study sample: As indicated in Table 5, of the 112 respondents, most of them were males constituting a percentage of (56.3). the age group (21-40 years) formed the highest percentage in the sample study with $(59.8 \%)$. Regarding the qualification level, bachelor degree holders accounted for $(45.5 \%)$. Last, but not least, the Medium level in the use of Internet was the highest proportion of respondents of the study sample with $63.4 \%$. 
Table 5: Sample Characteristics

\begin{tabular}{|c|c|c|c|}
\hline Percentage & Number & \multicolumn{2}{|c|}{ Demographic } \\
\hline $56.3 \%$ & 63 & Male & \multirow{2}{*}{ Gender } \\
\hline $43.7 \%$ & 49 & Female & \\
\hline $19.6 \%$ & 22 & (20) years and less & \multirow{3}{*}{ Age } \\
\hline $59.8 \%$ & 67 & $(21-40)$ years & \\
\hline $20.6 \%$ & 23 & (41) years and more & \\
\hline $22.3 \%$ & 25 & Less than BA & \multirow{3}{*}{ Qualifications } \\
\hline $45.5 \%$ & 51 & BA & \\
\hline $32.2 \%$ & 36 & Postgraduate & \\
\hline $16 \%$ & 18 & Beginner & \multirow{3}{*}{$\begin{array}{l}\text { Level in } \\
\text { Internet use }\end{array}$} \\
\hline $63.4 \%$ & 71 & Medium & \\
\hline $20.4 \%$ & 23 & Professional (Top) & \\
\hline
\end{tabular}

Hypotheses testing and statistical analysis: In general, the ultimate goal of quantitative research is testing the existing theory through conceptual framework (research model) development and testing its assumptions or hypotheses (Bryman \& Bell, 2007). Statistical testing of the study hypotheses is conducted in order that a decision is made to reject or accept them. The general rule of the rejection or the acceptance decision is that if the p-value is greater than the identified level of significance (i.e. $\alpha$-level that is usually $5 \%$ in social research), then the null hypothesis cannot be rejected and no support will be claimed for the alternative hypothesis (Abu Assi et al., 2014). On the other hand, if the $p$-value is less than or equal to the level of significance ( $\alpha$-level), then the null hypothesis will be rejected and the alternative hypothesis will be supported (Sekaran, 2003). Analysis of Variance (ANOVA), Multiple Regression and One Way Analysis of Variance were used to test the main hypotheses of the study. One Way Analysis of Variance was used to test the effect of the clients' demographics on a client's e-trust in online banking systems (i.e. the third 
main null hypothesis). Before applying multiple regression analysis, an important statistical test should be undertaken, which is the Multicollinearity analysis that denotes to a strong association between two or more independent variables in the regression model. Multicollinearity can be checked by conducting two popular measures; the Variance Inflation Factor (VIF) and the Tolerance test. If the VIF is greater than (10) and if the tolerance is below (0.1), then there is a problem (i.e. Multicollinearity exists). The (VIF) and the tolerance test results are depicted in Table 6.

Table 6: (VIF) and Skewness Coefficient Test

\begin{tabular}{|c|c|c|l|}
\hline Skewness & (VIF) & Allowable Tolerance & \multicolumn{1}{|c|}{ Variables } \\
\hline 0.093 & 3.105 & .322 & Information quality \\
\hline $0.140-$ & 4.708 & .212 & System design \\
\hline $0.074-$ & 3.246 & .308 & Perceived value \\
\hline $0.300-$ & 4.808 & .208 & $\begin{array}{l}\text { Imposed commission } \\
\text { (service price) }\end{array}$ \\
\hline $0.441-$ & 2.891 & .346 & Social factors \\
\hline
\end{tabular}

In order to investigate the normality of distribution of data, the value of skewness coefficients should be less than (1). The one can see from Table 6 , that skewness coefficients are ranging from $(-0.441)$ to $(0.093)$ and this means that there is no problem with the normality of distribution of data.

Table 7: Analysis of Variance (ANOVA)

\begin{tabular}{|c|c|c|c|c|c|c|c|}
\hline $\begin{array}{c}\text { level of } \\
\text { significance }\end{array}$ & F value & $\begin{array}{c}\text { squares } \\
\text { average }\end{array}$ & $\begin{array}{c}\text { Freedom } \\
\text { degree }\end{array}$ & $\begin{array}{c}\text { Squares } \\
\text { sum }\end{array}$ & $\mathrm{R}^{2}$ & Source & $\begin{array}{c}\text { Dependant } \\
\text { variable }\end{array}$ \\
\cline { 1 - 7 } & 142.688 & 402.254 & 5 & 2011.270 & \multirow{2}{*}{0.876} & regressionE-trust in online \\
banking
\end{tabular}

Testing the first main hypothesis: Table 7 shows the analysis of variance (ANOVA) results to statistically test the 
main first hypothesis of the study. It can be concluded from Table 7 that the $F$ value is (142.688), which is significant at the level of $p<0.05$ (sig. =.000). As a result, the main first hypothesis of the study was accepted that denoted to the fact that the independent variables taken together have an effect on the client's e-trust in online banking systems. Table 7 shows that $(87.6 \%)$ of the variance in the dependent variable (i.e. e-trust) is explained by the variance in the independent variable.

Table 8: Multiple regression analysis

\begin{tabular}{|c|c|c|c|c|c|}
\hline $\begin{array}{c}\text { level of } \\
\text { significance }\end{array}$ & T value & Beta & $\begin{array}{c}\text { Standard } \\
\text { error }\end{array}$ & B & $\begin{array}{c}\text { The dimensions of online banking } \\
\text { system }\end{array}$ \\
\hline .004 & $2.915-$ & & .706 & $2.058-$ & (Constant) \\
\hline .016 & 2.457 & .152 & .098 & .241 & Information quality \\
\hline .000 & 3.921 & .298 & .093 & .365 & System use \\
\hline .044 & 2.043 & .129 & .097 & .199 & Perceived value \\
\hline .029 & 2.209 & .170 & .120 & .265 & mposed commission (service price \\
\hline .000 & 4.951 & .295 & .101 & .498 & Social factors \\
\hline
\end{tabular}

Testing the first main hypothesis: as shown in Table 8, $\mathrm{T}$ values for the independent variables taken separately were (2.457, 3.921, 2.043, 2.209 and 4.951) showing significance at the level $\mathrm{P}<0.05$ (where sig. $=.016, .000, .044, .029, .000$ ) respectively. Consequently, the second main hypothesis and all of its sub hypotheses were accepted, which means that the independent variables have a direct impact on the client's e-trust in online banking systems taken separately.

Testing the first main hypothesis: To statistically test the third main hypothesis, one way analysis of variance was used as shown in tables (9-12) for the demographic variables gender, age, qualification and the level of internet use respectively. 2-independent-Samples T-test, to test differences in client's e- 
trust in online banking systems according to gender, has been used. Table 9 shows the results of t-test.

Table 9: T-test results for 2 -independent samples for the differences in client's e-trust in online banking systems according to gender

\begin{tabular}{|c|c|c|c|c|c|c|c|}
\hline $\begin{array}{c}\text { level of } \\
\text { significance }\end{array}$ & $(\mathrm{t})$ value & $\begin{array}{c}\text { Standard } \\
\text { error }\end{array}$ & $\begin{array}{c}\text { freedom } \\
\text { degree }\end{array}$ & number & $\begin{array}{c}\text { standard } \\
\text { deviation }\end{array}$ & $\begin{array}{c}\text { arithmetic } \\
\text { mean }\end{array}$ & Gender \\
\hline 0.556 & -0.591 & 0.92 & 105 & 63 & 4.68 & 14.78 & Male \\
\hline & & & & 49 & 4.63 & 15.33 & Female \\
\hline
\end{tabular}

Table 9 shows that $\mathrm{T}$ value is $(-0.591)$, which is significant at level of $\mathrm{P}>0.05$ ( $\mathrm{sig}=0.556)$. Hence, there is no significant difference in the client e-trust in online banking systems according to gender.

Table 10: One way analysis of variance for the differences in client's e-trust in online banking systems according to age

\begin{tabular}{|c|c|c|c|c|c|}
\hline $\begin{array}{c}\text { level of } \\
\text { significance }\end{array}$ & F value & $\begin{array}{c}\text { Square } \\
\text { mean }\end{array}$ & $\begin{array}{c}\text { degree of } \\
\text { freedom Df }\end{array}$ & $\begin{array}{c}\text { Squares } \\
\text { sum }\end{array}$ & $\begin{array}{c}\text { Source of } \\
\text { variation }\end{array}$ \\
\hline .000 & 1045 & 21919.155 & 1 & 21919.155 & Between groups \\
\hline .069 & 2.740 & 57.470 & 2 & 114.940 & age \\
\hline & & 20967 & 104 & 2181.060 & Error \\
\hline & & & 107 & 26371.000 & Total \\
\hline
\end{tabular}

Table 10 shows that $F$ value is (2.740) with a ( $\mathrm{sig}=0.069)$, above the significance level of $\mathrm{P}>0.005$, this result means that there is no significant difference in the client e-trust in online banking systems according to age. 
Table 11: One way analysis of variance for the differences in client's e-trust in online banking systems according to qualification

\begin{tabular}{|c|c|c|c|c|c|}
\hline $\begin{array}{c}\text { level of } \\
\text { significance }\end{array}$ & F value & $\begin{array}{c}\text { Square } \\
\text { mean }\end{array}$ & $\begin{array}{c}\text { degree of } \\
\text { freedom Df }\end{array}$ & $\begin{array}{c}\text { Squares } \\
\text { sum }\end{array}$ & $\begin{array}{c}\text { Source of } \\
\text { variation }\end{array}$ \\
\hline .000 & 238.779 & 4485.242 & 1 & 4485.242 & Between groups \\
\hline .000 & 9.115 & 171.226 & 2 & 342.452 & qualification \\
\hline & & 18.784 & 104 & 1953.548 & Error \\
\hline & & & 107 & 26371.000 & Total \\
\hline
\end{tabular}

Table 11 shows that the $F$ value (9.115) is significant below 0.05 , which means that there is a significant differences in the clients' e-trust in online banking systems according to clients qualifications.

Table 12: One way analysis of variance for the differences in client's e-trust in online banking systems according to Level of Internet use

\begin{tabular}{|c|c|c|c|c|c|}
\hline $\begin{array}{c}\text { Level of } \\
\text { significance }\end{array}$ & F value & $\begin{array}{c}\text { Square } \\
\text { mean }\end{array}$ & $\begin{array}{c}\text { degree of } \\
\text { freedom df }\end{array}$ & $\begin{array}{c}\text { Squares } \\
\text { sum }\end{array}$ & $\begin{array}{c}\text { Source of } \\
\text { variation }\end{array}$ \\
\hline .000 & 1020 & 22191.166 & 1 & 22191.166 & Between groups \\
\hline .000 & 2.710 & 56.660 & 2 & 116.940 & Level of internet use \\
\hline & & 22247.826 & 104 & 2281.060 & Error \\
\hline & & & 107 & 27373.000 & Total \\
\hline
\end{tabular}

Table 12 shows that the $F$ value (2.710) is significant below 0.05 , which means that there is a significant differences in the client e-trust in online banking systems according to the level of Internet use. 
Results Discussion and Recommendations: This section presents a comprehensive description of the results and discussions of this study.

\section{Results discussion:}

In this study, the results showed that the independent variables taken together or taken separately have an effect on the client's e-trust in online banking systems. Thus, the first and the second alternative hypothesis were accepted and a significant impact of the independent variables was found on client's e-trust in online banking systems. As for analysis of the respondents' demographic characteristics (age, gender, qualification and level of internet use) and their effect on client's e-trust in online banking systems, the results revealed the following: investigating the effect of gender on client's e-trust in online banking systems, there was no significant difference in the client e-trust in online banking systems according to gender. This can be attributed to the fact that online banking systems do not discriminate between male and female users in the gender in the provision of banking service and technical support.

Regarding age, the results showed that there were no differences in respondents' e-trust in online banking systems according to age. Although researchers in the literature agreed that young people are likely to be more sensitive to internet banking adoption (Abu Assi et al., 2014), it seems that users who already utilize the system might know how to use the online banking system properly. In addition, the results indicated that were significant differences in client's e-trust in online banking systems according to qualifications of users. Postgraduate degree, for instance, revealed the highest mean of e-trust in online banking systems, which means education and academic 
qualifications play an active role in assisting customers to use and deal with the system and as a result, trust the system more than their peers of bachelor and less than bachelor degree.

Additionally, the results indicated that there were significant differences in the customers' e-trust in online banking system according to the level of Internet use. The result can be contributed to the fact that the more the customer uses the system, the higher level of experience is gained and therefore, the one will be more capable of dealing with the system and trust the system.

\section{Recommendations:}

This study is considered valuable to the Jordanian banking sector as it provides a comprehensive model of the factors that affect clients' e-trust in online banking systems, which were technical, economic and social factors.

The current study presents a set of recommendations:

1. Jordanian banks should pay more attention on designing user friendly online banking systems by making them easy to learn, understand and use to encourage less educated clients to use online banking systems.

2. Marketing departments in Jordanian banks should conduct more research on the factors that lead to enhanced trust in online systems, which should lead clients to rely heavily on online banking systems to reap more benefits.

3. Jordanian banks should concentrate on the security and confidentiality issues of online banking systems by introducing security control procedures to ensure information security and privacy 
4. Create a legal and regulatory environment to create a clear framework for the recognition of electronic signatures and digital certificates.

\section{References:}

- Abu-Assi, H., Al-Dmour, H., \& Al-Zu'bi, Z. (2014), "Determinants of Internet Banking Adoption in Jordan", International Journal of Business and Management; Vol. 9, No. 12

- Adams, J.S. (1965) "Inequality in Social Exchange", Advances in Experimental Psychology, L. Berkowitz (ed.), Academic Press, New York, NY. pp. 267-299.

- Aladwani, A.M.(2001)."Online Banking: A Field Study of Drivers, Development Challenges and Expectations". International Journal of Information Management 21 (4), 213-225.

- AlKailani, M., (2016), "Factors Affecting the Adoption of Internet Banking in Jordan:An Extended TAM Model", Journal of Marketing Development and Competitiveness Vol. 10(1)

- Allen, L.E. (1996), "Electronic Commerce," Mortgage Banking, Vol. 56: 101-102,.

- Alsamydai, M., Yassen, S., Alnaimi, H,. Dajani, D., \& ALQirem, I., (2014), "The Factors Influencing Customer Usage Of Mobile Banking Services In Jordan”, International Journal of Business Management \& Research, Vol. 4, Issue 2, 63-78

- Ba, S., Pavlou, P.A., (2002). "Evidence of the effect of trust building technology in electronic markets: price premiums and buyer behavior'. MIS Quarterly 26 (3), 243-268.

- Baraghani, S.M., (2008), "Factors Influencing the Adoption of Internet Banking. Master Thesis", Lulea University of 
Technology,

Sweden

Retrieved

from 〈https://pure.ltu.se/ws/files/31102242/LTU-PB-EX-

08099-SE.pdf $\rangle$

- Barnes, J.G.,(1997) "Exploring the Important of Closeness in Customer Relationship," Proceeding of American Marketing Association Conference, Dublin: 227-238.

- Berry, L.L. (1995), "Relationship Marketing of ServiceGrowing Interest, Emerging Perspectives," Journal of the Academy of Marketing Science, Vol. 23: 236-245.

- Bryman, A. and Bell, E. (2007). Business research methods. Second edn. Oxford. Oxford University Press.

- Chang, H.H. and H.W. Wang. (2011), "The Moderating Effect of Customer Perceived Value on Online Shopping Behavior", Online Information Review, Vol. 35, No. 3:333359.

- Chang, H.H., Y.H. Wang and W.Y. Yang .( 2009), "The Impact of E-Service Quality, Customer Satisfaction and Loyalty on E-Marketing: Moderating Effect of Perceived Value," Total Quality Management \& Business Excellence, Vol. 20,No. 4:423-443.

- Chiang, K.-P. and R.R. Dholakia . (2003), "Factors Driving Consumer Intention to Shop Online: An Empirical Investigation," Journal of Consumer Psychology, Vol. 13, No. 1-2:177-183.

- Chiou, W.C., C.C. Lin and C. Perng (2010), "A Strategic Framework for Website Evaluation Based on a Review of the Literature from 1995-2006," Information \& Management, Vol. 47, No. 5-6:282-290.

- Corbitt . Brian J., Theerasak Thanasankit, Han Yi (2003), "Trust and E-Commerce: A Study of Consumer Perceptions", Electronic Commerce Research and Applications 2 (2003) $203-215$. 
- Currall, S., and Judge, T., (1995), "Measuring Trust Between Organizational Boundary Role Persons", Organizational Behavior and Human Decision Processes, 64(2), 150-170

- Dai, H., A.F. Salam and R. King (2008), "Service Convenience and Relational Exchange in Electronic Mediated Environment: An Empirical Investigation". Paper presented at the 29th International Conference on Information Systems (ICIS 2008), Paris, France, 14-17 December.

- Dayal, S., Landesbeg, H., Zeisser, M., (1999), "How to Build Trust Online", Marketing Management 8 (3), 64-69.

- EL-Said, G.F and G.H .Jalal-edeen. (2009), "The Rule of Culture in E-Commerce Use for the Egyptian Consumers" business process management journal, vol.15,1,pp34-47.

- Gefen, D., (2000). "E-commerce: the Role of Familiarity and Trust. OMEGA: The International Journal of Management Science 28 (6), 725-737.

- Gefen, D., Karahanna, E. \& Straub, D. W. (2003). "Trust and TAM in Online Shopping: An Integrated Model", MIS Quarterly, 27(1):51-90.

- Ghane, S., M. Fathian and M.R. Gholamian, (2011)." Full Relationship among e-Satisfaction, e-Trust, e-Service Quality, and e-Loyalty: The Case of Iran e-Banking. J. Theor. Appl. Inf. Technol.", 33: 1-6.

- Heider, F. (1958), The Psychology of Interpersonal Relations, New York, Wiley,.

- Henczel, S.(2004), "Creating User Profiles to Improve Information Quality," Online (May/Jun), Vol. 28: 30-33.

- Igbaria, M., Zinatelli, N. and Cavaye, A. L. M. (1998). Analysis of Information. Technology Success in Small Firms in New Zealand. International Journal of Information Management, 18(2), 103-119 
- Jiang, P. and Rosenbloom, B. (2005), "Customer Intention to Return Online: Price Perception, Attribute-level Performance, and Satisfaction Unfolding Over Time." European Journal of Marketing. Vol. 39, No. 1/2, pp. 150-174

- Kadomi T., (2008), "Factors Affecting the Spread of Electronic Banking, an Empirical Study on the Jordanian Commercial Banking " Jordanian magazine for applied science, $\operatorname{vol}(11)$,no(2), pp 293-312

- Kang, Y. and Y. Kim . (2006), "Do Visitors Interest Level and Perceived Quality of Webpage Content Matter in Shopping the Attitude toward a Web Site?" Decision Support Systems, Vol. 4: 1182-1201.

- Lee, J., J. Kim, and J.Y. Moon, (2000 ) "What Makes Internet Users Visit Cyber Stores Again? Key Design Factors for Customer Loyalty," Proceedings of the CHI 2000 conference on Human factors in computing systems, 305312.

- Lee, Y. and K. Kozar. (2006) "Investigating the Effort of Website Quality on e-Business Success: An Analytic Hierarchy Process (AHP) Approach," Decision Support Systems, Vol. 42: 1383-1401.

- Liljander, V. and T. Strandvik. (1995) "The Nature of Customer Relationships in Service," Advances in Services Marketing and Management, Vol.4: 141-167,

- Luarn, P. and H.H. Lin. (2003), "A Customer Loyalty Model for E-service Context" Journal of Electronic Commerce Research, Vol. 4, No. 4:156-167.

- Margaret Tan \& Thompson S. H. Teo (2000), "Factors Influencing the Adoption of Internet Banking", Journal of the Association for Information Systems, Volume 1, Article 5. 
- Mayer, R. C., Davis, J. H. and Schoorman, F.D. (1995). "An Integrative Model of Organizational Trust", Academy of Management Review, V. 20, N. 3, pp. 709-734.

- Md Nor, K. \& Pearson, J. M. (2007). "The Influence of Trust on Internet Banking Acceptance" Journal of Internet Banking and Commerce, 12(2).

- Morris, M.H., J. Brunnyee, and M. Page.( 1998) "Relationship Marketing in Practice-Myths and Realities," Industrial Marketing Management, Vol. 27: 359-371.

- Morrison .D.E. and J.Firmstone (2000), "The Social Function of Trust and Implication for E-commerce ", International Journal for Advertizing, Vol 19 ,pp 1599-1623

- Nasri Wadie (2011), "Factors Influencing the Adoption of Internet Banking in Tunisia ", International Journal of Business and Management, Vol. 6, No. 8

- Nielson, C.C.(1998), "An Empirical Investigation of the Role of "Closeness" in Industrial Buyer-Seller Relationships" European Journal of Marketing, Vol. 32: 441-463.

- Perkins, Ed-Zilla Daniel . Annan, Jonathan (2013) . "Factors Affecting the Adoption of Online Banking in Ghana: Implications for Bank Managers", International Journal of Business and Social Research (IJBSR), Volume -3, No.-6, June.

- Perry, C., A. Cavaye, and L. Coote. (2002) "Technical and Social Bonds within Business-to-Business Relationships," Journal of Business and Industrial Marketing, Vol. 17, No. 1: 75-86.

- Phillips, H.( 2004.), "Is Empathy an Animal Quality?" New Scientist, Vol. 182: 15,

- Quan, S. (2010), "Assessing the Effects of E-service Quality and E-satisfaction on Internet Banking Loyalty in China". Paper presented at the 1 st International Conference on E- 
Business and E-Government (ICEE 2010), Guangzhou,China, 7-9 May. IEEE, Los Alamitos, CA, pp. 93-96.

- Reichheld, F.F. and Schefter, P. (2000) " Eloyalty: Your Secret Weapon on the Web' Harvard Business Review, 78(4), 105-114.

- Rousseau, D.M., Sitkin, S.B., Burt, R.S., Camerer, C., (1998). "Not So Different After All: a Cross-Discipline View of Trust". Academy of Management Review 23 (4), 393-404.

- Salam, A, Palvia,P. Singh,R (2005) "Trust in E-commerce" International Journal of Electronic Commerce, vol 11, no(3) ,pp.107-134

- Sekaran ,Uma,(2003), "Research Methods For Business " ,John Wiley \& Sons.

- Sharma, Sharil (2014). "The Pragmatic Review on Internet Banking and Associated Services in India", International Journal of Computing and Corporate Research ISSN (Online) : 2249-054X Volume 4 Issue 4.

- Shih, Y.Y., and K. Fang. (2004)." The Use of Decomposed Theory of Planned Behavior to Study Internet Banking in Taiwan". Internet Research, 14(3): 213-23.

- Siam, A., (2006), "Role of the Electronic Banking Services on the Profits of Jordanian Banks", American Journal of Applied Sciences, 3(9)

- Sohrabi Maryam, Yee Julie and Nathan Robart (2013), "Critical Success Factors for the Adoption of E-banking in Malaysia" , International Arab Journal For E-Technology, Vol. 3, No. 2

- Swaid, S.I. and R.T. Wigand .( 2009), "Measuring the Quality of E-service: Scale Development and Initial Validation," Journal of Electronic Commerce Research, Vol. 10, No. 1:13-28. 
- Venkatesh, V., et al. (2003). "User Acceptance of Information. Technology: Toward a Unified View". MIS Quarterly, 27(3), 425- 478. 